JURNAL SENI MUSIK

\title{
IMITATION IN THE JARANAN BUTO BANYUWANGI MUSICAL PRESENTATION STRUCTURE
}

\section{Handi Wiyono}

Fakultas Sastra, Universitas Negeri Malang, Indonesia

\begin{abstract}
Article Info
Submitted : April, 2021

Revised : May, 2021

Accepted : May, 2021

Abstract

Keywords:

Jaranan Buto, Imitation,

Accompaniment Music

Jaranan Buto is one of the arts that live in Banyuwangi in addition to other arts. As a performing art, in every presentation Jaranan Buto uses accompanying music. At the beginning of its creation, the musical accompaniment of Jaranan Buto consisted of several instruments and pieces. Over time, the musical accompaniment of Jaranan Buto has experienced developments so as to form a structure for presenting the musical accompaniment of Jaranan Buto which is now commonly used. This study discusses the structure of the musical accompaniment of Jaranan Buto and its various imitations. This study used a descriptive qualitative approach by interviewing Setro Asnawi (80 years) as the creator of Jaranan Buto and Mariyono (55 years) as the second generation of Jaranan Buto Sekar Diyu dancers who were still active until this research was written. Analysis of research data starts from domain analysis, observation focused on the accompaniment of Jaranan Buto from the beginning of the stage, trance to exiting the stage, taxonomic analysis, selected observations to the final stage, namely component analysis. From these results it can be concluded that the elements of musical imitation in the accompaniment of Jaranan Buto consist of imitation of musical instruments and imitation of pieces performed from other arts.
\end{abstract}




\section{INTRODUCTIONS}

Jaranan Buto is one of the arts that is owned by Banyuwangi Regency. This art lives and develops in addition to other arts such as gandrung, kuntulan, angklung caruk, janger and so on, which are the cultural diversity that Banyuwangi has. "This diversity can be seen based on the culture of the people, which are predominantly divided into three ethnicities, namely the Javanese Mataraman ethnicity, the Madurese Pandalungan ethnicity, and the Using ethnicity"(Agung \& Soetopo, 2019). Ethnic diversity is what eventually gave birth to culture, especially diverse arts. Jaranan Buto is an art that lives and develops rapidly in the southern Banyuwangi area, where the majority of the population is Javanese. This art was created by a man named Setro Asnawi from Trenggalek who moved to Banyuwangi in 1963. He created and started Jaranan Buto in 1964 around June and July and finally founded the Jaranan Buto group called Sekar Diyu.

Jaranan Buto art in its performance is presented for one day usually shown from 10.00 to 16.00 WIB. At the peak of the show, usually the Butho jaranan dancers experience a trance (Dwi Handoko, 2014). The order of presentation in the performance for a day is starting from a piece dish, six dancers, jaranan dancers four people, jaranan dancers two people, kucingan and dagelan, jaranan dancers two people, jaranan dancers two people, and lastly, jaranan dancers six people. with barongan and piggy bank (interview with Setro Asnawi, 20 November 2020). Every performance that presents jaranan dancers, whether two, four, or six people will end with trance except for six in the last dish which ends with a war against Barongan and the piggy bank.

For each, Jaranan Buto is accompanied by accompanying music. The music at Jaranan Buto is used to accompany the dance in every scene for a full day. At the beginning of its creation, the musical accompaniment at Jaranan Buto consisted of several musical instruments, namely a drum, a pair of kenong, kempul and gong, selompret, and three angklung. Now in its development, "it has innovated so rapidly, including variations in the accompanying music, the make-up of the dancers, the costumes worn by the dancers have been innovated so rapidly every year" (Dwi Handoko, 2014). This development cannot be separated from the adaptations and imitations made. Gudykunts and Kim said adaptation is influenced by factors "namely personal communication, host social communication, ethnic social communication, environment, and predisposition" (Utami, 2016). Meanwhile, imitation is a process cognition to carry out actions or actions as carried out by model by involving senses as the recipients excitatory and mounting capabilities perception to process information from stimuli with the ability action to do motor movements (source: https://id.wikipedia.org/wiki/Imitasi).

The musical accompaniment of Jaranan Buto developed in terms of several aspects. These developments form a musical aesthetic that can be seen from the intrinsic values of music itself, as well as in terms of psychological relationships to human life (Sunarto, 2016). This musical aesthetic is contained in the current accompaniment of Jaranan Buto which will be discussed in this paper, especially in the imitation section. The imitation of accompaniment music in the presentation structure discussed in this paper is limited to the presentation of the jaranan dancers, either two, four, or six people, which ends in trance.

\section{METHODS}

This research used a descriptive qualitative approach by conducting in-depth interviews with Setro Asnawi (80 years old) who was the creator of Jaranan Buto in Banyuwangi and Mariyono (55 years old) as the second generation of Jaranan Buto dancers, Sekar Diyu who was still active in jaranan dancing until the time this research was conducted. . In addition, direct observations were made on the Jaranan Buto Show of several groups / associations that could represent Jaranan Buto in Banyuwangi. Among them are Jaranan Sekar Mulyo, Jaranan Krido Yakso, Jaranan Taruna Sakti, Jaranan Pentul Budoyo, and Jaranan Rino Budoyo. The five samples of the Jaranan Buto group have the same Jaranan Buto presentation structure but have different characteristics of selecting musical instruments. Jaranan Sekar Mulyo uses additional musical instruments in the form of gangsa with Banyuwangi slendro tunes and pelog barang. Jaranan Krido Yakso uses musical instruments that are conservative in nature, namely the drum, a pair of kenong, selompret, kempul, angklung and gong. However, there are additional instruments in the form of a keyboard. Jaranan Taruna Sakti uses additional musical instruments in the form of gangsa with the Banyuwangi slendro and five-tone Pelog Gong Kebyar Bali. Jaranan Pentul Budoyo uses additional instruments of gangsa, kenong, and kempul with Javanese (Surakarta) slendro and 
seven-tone pelog. Jaranan Rino Budoyo used additional musical instruments, the gangsa pelog 5 tones of Gong Kebyar Bali. Thus, the five Jaranan Buto groups are considered capable of representing other Jaranan Buto groups in Banyuwangi which have the characteristics of adding similar musical instruments, some or the same. Researchers made observations during December 2018-January 2019, June-August 2019, and December 2019-January 2020. The focus of the researcher's observations was directed at the accompaniment of Jaranan Buto music from the start of entering the stage to exiting the stage which means that focusing on the Jaranan Buto scene is not the mouse scene, barongan, or piggy bank. Researchers also observed active participation in several groups / associations of Jaranan Buto. Analysis of research data begins with domain analysis, focused observation, taxonomic analysis, selected observations until the final stage, namely component analysis and data and research results are presented descriptively (Nugrahani \& Hum, 2014).

\section{RESULTS AND DISCUSSION}

Jaranan Buto is an art that lives in the Banyuwangi community as an art that functions as entertainment. The art of Jaranan Buto is widely displayed in the general public when there are celebratory events such as circumcision, weddings, and thanksgiving. This activity is called the response network. Jaranan responses are those that are considered or rented by the general public. A form of representation of network identities that is directly related to the market. Jaranan responses follow market tastes (Oktaviany, 2017). Based on the function of Jaranan Buto as entertainment, the presentation structure for each performance is the same.

The first Jaranan Buto group in Banyuwangi was named "Sekar Diyu" which was founded by Setro Asnawi in Cluring District. The musical accompaniment of Jaranan Buto originally consisted of a drum, kempul, gong, a pair of kenong, slompret, and three angklung with gendhing Gangsaran, Sampak, and Sanga. Over time, new Jaranan Buto groups emerged in other sub-districts in Banyuwangi Regency. The emergence of the new Jaranan Buto has triggered market competition, which ultimately makes each group / association have different characteristics. This difference is striking, especially in the accompaniment of music which can be seen from the two main elements, namely musical instruments and pieces. However, every Jaranan Buto in Banyuwangi when this research was written had the same order of presentation as follows:

\section{Gendhing Lancaran}

At the beginning, after the MC or the puppeteer tells the chronology or setting of a kingdom, suluk budhalan, then he conveys the name of the piece at the beginning to accompany Jaranan Buto, who will come out with a sabetan dance or also called bodholan. The pieces that are usually performed include Gumolong, Cing Cing Guling, Bata Rubuh (Lancaran Umbul-Umbul), Lancaran Gambuh, and Bendhe Beri. The main musical instruments in Jaranan Buto have remained the same from the beginning of their creation, namely the drums, kempul and gong, a pair of kenong, and selompret. Whereas in this section there are additional instruments, namely the gangsa, which can be in the form of the Banyuwangi gamelan instrument, the Balinese gamelan gong kebyar, and the Javanese gamelan. This additional instrument is not in the form of a complete set, but only demung, several sarons, and peking. The choice to decide which instrument to use (Banyuwangi, Bali, or Java) depends on each Jaranan Buto group. In this part as concrete is not played. Sometimes, there is also a substitute instrument for gangsa, namely the keyboard, such as one example in Jaranan Krido Yakso.

The choice of pieces and the form of this smooth piece depicts a firm warrior atmosphere, depicting valor and an atmosphere of patriotism. This choice is an imitation of the shadow puppet art release of soldiers can be accompanied by a gamelan instrument that is fast and enthusiastic, which tells the story of the advancement of the ranks of the soldiers, for example Lancaran Gambuh (Widyaswoko, 2018). This is a development because in the early days of its creation, it only used gendhing gangsaran with instruments such as drums, kempul, gong, slompret, and a pair of kenong. Joget Ukel Lincak Gagak accompaniment

The second part after the lancak pieces is the accompaniment of Ukel Joget Lincak Gagak's standard. This part is to accompany the Jaranan Buto players after all entering the stage and forming a line. In this section the musical instrument used is the main instrument of Jaranan Buto, as it was when it was created. Namely the drums, selompret, pair of kenong, kempul, and gong. There is only one group of Jaranan Buto who added the angklung instrument to accompany this dance dance, namely Jaranan Krido Yakso. This is in 
accordance with the form of the accompaniment of Jaranan Buto when it was first created (interview with Mariyono, 15 October 2020). In this presentation, there is a special Gendhing pattern, namely the ukel pattern on the kenong, kempul, and gong instruments that are characteristic of Jaranan Buto. Meanwhile, Selompret presents a special song and the drums play the accompaniment of Joget Ukel Lincak Gagak.

\section{Tayongan}

After the Ukel Lincak Gagak dance, continued the lawung movement or tayongan this motion is free motion (Wijayanti \& Puspito, 2021). In this section, the musical accompaniment of Jaranan Buto plays the accompaniment of tayongan or so-called song parts. This is because in this section the selompret function is usually replaced by the singing singer. The form of gending on structural instruments in this section is different from the previous section, namely the kempul and gong instruments. While the drum follows the dancer or can also guide the dancer using idioms and drum patterns commonly used in the tayongan section.

\section{Srampat}

After the tayongan part, it will be continued with a sling pattern. However, this section does not only use Srampat pieces but can also other pieces such as Sontoloyo pieces or pieces which have a pattern like Srampat and the drum pattern which is commonly called the Tulungagungan drum. The instrument that performed this piece was gangsa with sindhenan. The addition of this piece is an imitation of the art of Gandrung or tayub. As the opinion states that srampat slendro sanga which is usually used to accompany tayub (Utami \& Sugito, 2018). Initially, the imitation of this piece was initiated by the drummer Jaranan Sekar Diyu named Narto on the basis of his own creativity.

\section{Perang (War)}

This war scene is the first war scene depicting the beginning of a conflict within a group. In this section, the accompaniment music uses the same piece pattern as in Joget Ukel Lincak Gagak and uses slompret. The drum pattern in this section uses a special drum pattern called no-war and improvisation following the war movements of the dancer Jaranan Buto. This section is marked by the dancer Jaranan Buto who is still wearing a braided horse.

\section{Srepeg}

This part is the second war in which the Jaranan Buto players do not wear braids. In this section, sometimes some of the Jaranan players take off their crowns. The accompaniment used was srepeg with gangsa and sindhenan. The choice of the type of srepeg to be used depends on the gamelan player's agreement (panjak). The use of slingshot srepeg is an imitation of wayang art as All kinds of war in the presentation of the Jombor version of the Bratayuda play are accompanied by the form of slingshot Srepeg and Sampak (Krystiadi, 2010). The drum pattern in this section follows the movements of the dancer as an affirmation of motion.

\section{Guntur}

This section is marked by the presence of one of the players who is possessed. Usually the character who acts as the king / the one with the highest crown. This section is also marked by one of the characters who is in a trance being beaten by another player, such as being whipped, beaten, or kicked. The player who was possessed was chasing and avenging those who beat him. The musical accompaniment in this section is called the Gendhing Guntur which gives a tense atmosphere. The pattern and structure of this piece are almost the same as the sampak in the shadow puppet accompaniment. But what distinguishes is not used gangsa but selompret. The drum pattern uses improvisation following the movements of the dancer Jaranan Buto.

\section{Sampak}

Gandhing sampak on Jaranan Buto is to accompany players who are possessed dancing on their own. This section describes other players who are overwhelmed by beating players who are possessed and finally leave the stage until the remaining players are possessed dancing alone. The sampak gending uses a special structural instrument pattern with a slow tempo and is accompanied by a drum instrument, a pair of kenong, kempul, gong, and selompret. The drum pattern uses the idiom ndadi drum which is the hallmark of Jaranan Buto.

\section{Guntur}

At the end, the song Guntur was played again, as in the previous section, to accompany the trance players out of the stage. Before leaving the stage he danced slashes and left the stage assisted 
by Gambuh (Jaranan handler). The musical accompaniment of Jaranan Buto has developed from the beginning of its creation to the time this research was written. This development continued to occur until the formation of the Jaranan Buto presentation structure used by each group in Banyuwangi. Basically, the structure of the presentation of Jaranan Buto music in each group / association is the same. However, each of these groups has characteristics that differentiate it from other groups. Then the results of the analysis of this study lead to two aspects that are considered important and meaningful as research findings, namely the imitation results of the presentation structure of the musical accompaniment of Jaranan Buto for each group formed by components (1) musical instruments and (2) selection of pieces which are described as follows:

\section{Musical Instruments}

The musical instrument chosen to accompany Jaranan Buto is conservative but also growing. The conservative nature can be seen in the use of musical instruments such as the drums, kenong, kempul, gong, slompret, and angklung. But on the other hand, there are developments based on market goals and artist creativity. The addition of other instruments such as the Banyuwangi gangsa gamelan, the Balinese gamelan gamelan Gong Kebyar, as well as several Javanese gamelan instruments such as Demung, saron, kempul, and kenong. It is not uncommon for certain Jaranan Buto groups to add modern musical instruments such as keyboards. shows that each Jaranan Buto group has different characteristics and uniqueness. So that the aesthetic to express this beauty is manifested through the selection of different musical instruments.

\section{Gendhing}

The selection of pieces to accompany Jaranan Buto is also inseparable from the aesthetics of the suitability of the storyline brought by Jaranan Buto from the beginning of the dancer entering the stage to leaving the stage with the characteristics and nuances of the music presented. So that from there, pieces that are deemed suitable and represent each scene are selected, so that the storyline of Jaranan Buto can be more alive. From this awareness, each Jaranan Buto group / association performed imitation pieces from other arts and presented them to Jaranan Buto.

\section{CONCLUSION}

The accompaniment of Jaranan Buto music developed over time, starting from the beginning of its creation. From these developments, the structure of the presentation of the musical accompaniment of Jaranan Buto has become established and is used by each group / association of Jaranan Buto in Banyuwangi. The structure of the presentation of the musical accompaniment is used by each group / association of Jaranan Buto besides they perform imitations of other arts on musical instruments and pieces so that each group has different characteristics from other groups. In addition, the imitation of Jaranan Buto musical accompaniment is carried out while continuing to conserve musical instruments and parts of musical patterns that are considered important to form the structure of Jaranan Buto accompaniment. Thus, in its presentation, the musical accompaniment of Jaranan Buto has a unique value in each group which can be seen from the additional musical instruments and pieces performed which are the result of the imitation creativity of the art actors.

\section{REFERENCES}

Agung, R., \& Soetopo, D. (2019). Budaya Kesurupan Seni Tradisi Jaranan Di Banyuwangi. Universitas PGRI Banyuwangi

Dwi Handoko, A. (2014). Perkembangan Seni Tari Jaranan Buto Di Kecamatan Cluring Kabupaten Banyuwangi Tahun 1963-2007. Avatara, 2(3).

Krystiadi, N. (2010). Lakon Bra Tayuda Versi Jombor Sebuah Kajian Struktural. http://digilib.isi.ac.id/2292/

Nugrahani, F., \& Hum, M. (2014). Metode penelitian kualitatif. Solo: Cakra Books.

Oktaviany, D. (2017). Jaranan Kediri: Hegemoni Dan Representasi Identitas.

Sunarto, S. (2016). Estetika Musik: Autonomis versus Heteronomis dan Konteks Sejarah Musik. PROMUSIKA: Jurnal Pengkajian, Penyajian, dan Penciptaan Musik, 4(2), 102-116.

Utami, L. S. S. (2016). Teori-teori Adaptasi Antar Budaya. Jurnal Komunikasi, 7(2), 180-197. 


\section{Handi Wiyono/JURNAL SENI MUSIK (10) (1)}

Utami, R. F. S., \& Sugito, B. (2018). Proses

Kreativitas Janggrung Arena Menjadi

Pertunjukan Prosenium Melalui Karya

Tari "Tandhak Janggrung. Solah, 8(1).

Widyaswoko, W. (2018). Memaknai Perang

Baratayudha dalam Perspektif Kitab

Keluaran (Exodus). Jurnal Abdiel:

Khazanah Pemikiran Teologi, Pendidikan

Agama Kristen dan Musik Gereja, 2(1),

123-134.
Wijayanti, W. F., \& Puspito, P. (2021). Proses Kreatif Dan Manajemen Kelompok Jaranan Buto Setyo Budi Manunggal Desa Sidomukti Kecamatan Gambiran Kabupaten Banyuwangi. APRON Jurnal Pemikiran Seni Pertunjukan, 2(16). 